\title{
Front Matter: Volume 6536
}

, "Front Matter: Volume 6536," Proc. SPIE 6536, Saratov Fall Meeting 2006: Coherent Optics of Ordered and Random Media VII, 653601 (1 August 2007); doi: $10.1117 / 12.755483$

SPIE. Event: Saratov Fall Meeting 2006, 2006, Saratov, Russian Federation 


\title{
Saratov Fall Meeting 2006 Coherent Optics of Ordered and Random Media VII
}

\author{
Dmitry A. Zimnyakov \\ Nikolai G. Khlebtsov \\ Editors
}

26-30 September, 2006

Saratov, Russia

Organized by

Saratov State University named after N.G. Chernyshevsky (Russia)

Institute of Precision Mechanics \& Control, Russian Academy of Sciences

CRDF and Russian Ministry of Education and Science Research Educational Center on

Nonlinear Dynamics and Biophysics (REC-006)

Volga Region Center of New Information Technologies (Russia)

Cosponsored by

Russian Foundation for Basic Research

SPIE Russia Chapter

Saratov State University SPIE Student Chapter

U.S. Civilian Research \& Development Foundation for the Independent States

of the Former Soviet Union (CRDF)

"Almus" Ltd. (Russia)

Erudite-96, Ltd. (Russia)

Published by

SPIE

Volume 6536 
The papers included in this volume were part of the technical conference cited on the cover and title page. Papers were selected and subject to review by the editors and conference program committee. Some conference presentations may not be available for publication. The papers published in these proceedings reflect the work and thoughts of the authors and are published herein as submitted. The publisher is not responsible for the validity of the information or for any outcomes resulting from reliance thereon.

Please use the following format to cite material from this book:

Author(s), "Title of Paper," in Saratov Fall Meeting 2006: Coherent Optics of Ordered and Random Media VII, edited by Dmitry A. Zimnyakov, Nikolai G. Khlebtsov, Proceedings of SPIE Vol. 6536 (SPIE, Bellingham, WA, 2007) Article CID Number.

ISSN 0277-786X

ISBN 9780819466587

Published by

SPIE

P.O. Box 10, Bellingham, Washington $98227-0010$ USA

Telephone +1 3606763290 (Pacific Time) · Fax +1 3606471445

SPIE.org

Copyright (c) 2007, Society of Photo-Optical Instrumentation Engineers

Copying of material in this book for internal or personal use, or for the internal or personal use of specific clients, beyond the fair use provisions granted by the U.S. Copyright Law is authorized by SPIE subject to payment of copying fees. The Transactional Reporting Service base fee for this volume is $\$ 18.00$ per article (or portion thereof), which should be paid directly to the Copyright Clearance Center (CCC), 222 Rosewood Drive, Danvers, MA 01923. Payment may also be made electronically through CCC Online at copyright.com. Other copying for republication, resale, advertising or promotion, or any form of systematic or multiple reproduction of any material in this book is prohibited except with permission in writing from the publisher. The CCC fee code is $0277-786 \mathrm{X} / 07 / \$ 18.00$.

Printed in the United States of America.

Publication of record for individual papers is online in the SPIE Digital Library.

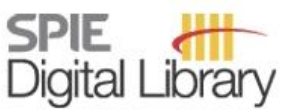

SPIEDigitalLibrary.org

Paper Numbering: Proceedings of SPIE follow an e-First publication model, with papers published first online and then in print and on CD-ROM. Papers are published as they are submitted and meet publication criteria. A unique, consistent, permanent citation identifier (CID) number is assigned to each article at the time of the first publication. Utilization of CIDs allows articles to be fully citable as soon they are published online, and connects the same identifier to all online, print, and electronic versions of the publication. SPIE uses a six-digit CID article numbering system in which:

- The first four digits correspond to the SPIE volume number.

- The last two digits indicate publication order within the volume using a Base 36 numbering system employing both numerals and letters. These two-number sets start with 00, 01, 02, 03, 04, 05, $06,07,08,09,0 \mathrm{~A}, 0 \mathrm{~B} \ldots \mathrm{OZ}$, followed by $10-1 \mathrm{Z}, 20-2 \mathrm{Z}$, etc.

The CID number appears on each page of the manuscript. The complete citation is used on the first page, and an abbreviated version on subsequent pages. Numbers in the index correspond to the last two digits of the six-digit CID number. 


\section{Contents}

vii Conference Committees
ix Introduction

SESSION 1 NANOSTRUCTURES AND NANOPARTICLES: OPTICAL PROPERTIES AND APPLICATIONS

653602 Optical properties of gold-nanoshell planar array [6536-01]

B. N. Khlebtsov, Institute of Biochemistry and Physiology of Plants and Microorganisms (Russia); V. A. Khanadeyev, Saratov State Univ. (Russia); D. A. Verin, Institute of Biochemistry and Physiology of Plants and Microorganisms (Russia); N. G. Khlebtsov, Institute of Biochemistry and Physiology of Plants and Microorganisms (Russia) and Saratov State Univ. (Russia)

653603 Multipole plasmons in gold nanorods: scaling properties and dependence on the particle size, shape, orientation, and dielectric environment [6536-02]

B. N. Khlebtsov, A. G. Melnikov, Institute of Biochemistry and Physiology of Plants and Microorganisms (Russia); N. G. Khlebtsov, Institute of Biochemistry and Physiology of Plants and Microorganisms (Russia) and Saratov State Univ. (Russia)

653604 Effect of microwave irradiation on composite iron oxide nanoparticle/polymer microcapsules [6536-03]

D. A. Gorin, Saratov State Univ. (Russia) and Max-Planck Institute of Colloids and Interfaces (Germany); D. G. Shchukin, Max-Planck Institute of Colloids and Interfaces (Germany); Yu. A. Koksharov, Moscow State Univ. (Russia); S. A. Portnov, Saratov State Univ. (Russia); K. Köhler, Max-Planck Institute of Colloids and Interfaces (Germany); I. V. Taranov, V. V. Kislov, Institute of Radio Engineering and Electronics (Russia); G. B. Khomutov, Moscow State Univ. (Russia); H. Möhwald, Max-Planck Institute of Colloids and Interfaces (Germany); G. B. Sukhorukov, Queen Mary Univ. of London (United Kingdom)

653605 Permeability adjustment of polyelectrolyte micro- and nanocapsules by laser irradiation [6536-04]

B. V. Parakhonskiy, Shubnikov Institute of Crystallography (Russia) and Moscow State Univ. (Russia); T. V. Bukreeva, Shubnikov Institute of Crystallography (Russia); G. V. Parakhonskiy, Shubnikov Institute of Crystallography (Russia) and Moscow State Univ. (Russia);

A. G. Skirtach, Max Planck Institute of Colloids and Interfaces (Germany); G. B. Sukhorukov, Shubnikov Institute of Crystallography (Russia) and Queen Mary Univ. of London (United Kingdom); N. G. Khlebtsov, Institute of Biochemistry and Physiology of Plants and Microorganisms (Russia); L. A. Feigin, M. V. Kovalchuk, Shubnikov Institute of Crystallography (Russia)

653606 Investigation of absorption and reflection spectra of aqueous suspensions of nanoparticles in the $X$ band of microwave bandwidth [6536-05]

S. A. Sergeev, S. A. Portnov, D. A. Gorin, A. I. Mikhailov, S. S. Rumyantseva, Saratov State Univ. (Russia); I. V. Taranov, V. V. Kislov, Institute of Radio Engineering and Electronics (Russia); G. B. Sukhorukov, Max-Planck Institute of Colloids and Interfaces (Germany) and Queen Mary Univ. of London (United Kingdom) 
653607 Fabrication of planar iron oxide nanocomposite films and investigation of their optical and magnetic properties [6536-06]

D. A. Gorin, Saratov State Univ. (Russia); D. O. Grigorev, Max-Planck Institute of Colloids and Interfaces (Germany); A. M. Yashchenok, Saratov State Univ. (Russia); Yu. A. Koksharov, Moscow State Univ. (Russia); A. A. Neveshkin, A. V. Pavlov, Saratov State Univ. (Russia); G. B. Khomutov, Moscow State Univ. (Russia); H. Möhwald, Max-Planck Institute of Colloids and Interfaces (Germany); G. B. Sukhorukov, Queen Mary Univ. of London (United Kingdom)

653608 About both concentration and size effect on optical spectra of polymer composite nanomaterials based on cadmium sulfide and low density polyethylene [6536-07] D. M. Kul'batsky, Saratov Technical State Univ. (Russia); N. M. Ushakov, I. D. Kosobudsky, Institute of Radio Engineering and Electronics (Russia); G. Yu. Yurkov, N.S. Kurnakov Institute of General and Inorganic Chemistry (Russia)

653609 Carbon nanotubes aligning by Langmuir-Blodgett technique and visualizing by nematic liquid crystals [6536-08]

A. Sadovoy, Y. Dubovik, V. Nazvanov, Saratov State Univ. (Russia)

6536 OA Handling of nanoparticles with light pressure forces [6536-09]

I. V. Fedosov, Saratov State Univ. (Russia); I. S. Nefedov, Institute of Radio Engineering and Electronics (Russia); B. N. Khlebtsov, Institute of Biochemistry and Physiology of Plants and Microorganisms (Russia); V. V. Tuchin, Saratov State Univ. (Russia)

$6536 \mathrm{OB}$ Application of gold nanoparticles to $\mathrm{x}$-ray diagnostics and photothermal therapy of cancer [6536-10]

G. S. Terentyuk, The First Veterinary Clinic (Russia); I. L. Maksimova, V. V. Tuchin, Saratov State Univ. (Russia); V. P. Zharov, Univ. of Arkansas for Medical Sciences (USA);

B. N. Khlebtsov, V. A. Bogatyrev, L. A. Dykman, N. G. Khlebłsov, Institute of Biochemistry and Physiology of Plants and Microorganisms (Russia)

6536 OC Diagnostic potentialities of plasmon-resonant nanoparticles as contrast agents for the diffuse back scattering spectroscopy of biotissues [6536-11]

I. L. Maksimova, Saratov State Univ. (Russia); G. S. Terentyuk, The First Veterinary Clinic (Russia); E. A. Genina, A. A. Skaptsov, V. V. Tuchin, Saratov State Univ. (Russia);

B. N. Khlebtsov, Institute of Biochemistry and Physiology of Plants and Microorganisms (Russia); V. A. Bogatyrev, N. G. Khlebtsov, Saratov State Univ. (Russia) and Institute of Biochemistry and Physiology of Plants and Microorganisms (Russia)

\section{SESSION 2 OPTICAL POLARIMETRY: FUNDAMENTALS AND APPLICATIONS}

6536 OD Orthogonal properties of homogeneous anisotropy medium [6536-12]

S. N. Savenkov, Y. V. Aulin, Taras Shevchenko Kyiv National Univ. (Ukraine)

$6536 \mathrm{OE}$ Inverse problem of polarimetry for homogeneous anisotropy media on basis of Mueller matrix calculus [6536-13]

S. N. Savenkov, Y. A. Oberemok, Kiev Taras Shevchenko Univ. (Ukraine)

6536 OF Mueller matrix models of the object with isotropic depolarization: experiment [6536-14] S. N. Savenkov, Y. A. Oberemok, V. V. Yakubchak, Yu. A. Skoblya, Kiev Taras Shevchenko Univ. (Ukraine) 
6536 OG Invariance of anisotropy properties presentation in scope of polarization equivalence theorems [6536-15]

S. N. Savenkov, I. S. Marfin, Kiev Taras Shevchenko Univ. (Ukraine)

$6536 \mathrm{OH}$ Optical properties of multi-domain anisotropic layers with random in-plain orientation of domains [6536-16]

M. M. Sherman, D. A. Yakovlev, Saratov State Univ. (Russia)

6536 ol Single-polarizer method for measurement of polarization characteristics of incoherent backscattering from anisotropic media [6536-17]

A. V. Spivak, O. A. Druzhina, Yu. P. Sinichkin, D. A. Yakovlev, Saratov State Univ. (Russia)

6536 0J Complete and incomplete imaging Mueller matrix polarimetry of homogeneous anisotropic media [6536-18]

S. N. Savenkov, Yu. A. Oberemok, A. S. Klimov, Yu. A. Skoblya, N. A. Obukhov, National Taras Shevchenko Univ. of Kyiv (Ukraine)

\section{SESSION 3 COHERENCE-DOMAIN TECHNIQUES}

6536 OK Correlation technique for exploration of local features of emission spectrum of laser and superluminescence diodes [6536-19]

V. V. Lychagov, A. L. Kalyanov, D. V. Lyakin, V. P. Ryabukho, Saratov State Univ. (Russia);

S. N. Sokolov, INJECT Inc. (Russia)

6536 OL Dual-wave heterodyne reflectometer based on femtosecond Cr:forsterite laser for investigation of light pulse propagation dynamics in strongly scattering media [6536-20] V. M. Gordienko, A. N. Konovalov, A. S. Khomenko, M.V. Lomonosov Moscow State Univ. (Russia)

$65360 \mathrm{M}$ Sensing an aqueous Intralipid suspension with optical coherence tomography: reconstruction of the scattering coefficients [6536-21]

N. Ayari, Univ. Jean Monnet (France); A. Popov, M. Kinnunen, R. Myllylä, Univ. of Oulu (Finland); F. Zhang, Qingdao Univ. (China)

$65360 \mathrm{~N}$ Measuring changes in the scattering properties of Intralipid at different depths with optical coherence tomography [6536-22]

M. Kinnunen, R. Myllylä, Univ. of Oulu (Finland)

653600 Comparing low coherence interferometry with conventional methods of measuring paper roughness [6536-23]

T. Prykäri, E. Alarousu, R. Myllylä, Univ. of Oulu (Finland)

6536 OP Optical coherence tomography of paper: Monte Carlo simulation for multilayer model [6536-24]

M. Yu. Kirillin, Univ. of Oulu (Finland) and M.V. Lomonosov Moscow State Univ. (Russia); R. Myllylä, Univ. of Oulu (Finland); A. V. Priezzhev, M.V. Lomonosov Moscow State Univ. (Russia) 
$65360 Q \quad$ Low-coherent autocorrelation interferometry [6536-25]

V. V. Lychagov, Saratov State Univ. (Russia) and Institute of Precision Mechanic and Control (Russia); D. V. Lyakin, V. P. Ryabukho, Institute of Precision Mechanic and Control (Russia) and Saratov State Univ. (Russia); M. M. Model, Beth Israel Deaconess Medical Ctr., Harvard Medical School (USA)

6536 OR Neuronet algorithms of data processing in the laser interferometer circuit when detecting low oscillations and vibrations of the object [6536-26]

A. A. Sirota, V. G. Popov, V. A. Shulgin, Voronezh State Univ. (Russia); D. K. Proskurin, Voronezh State Univ. of Architecture and Construction (Russia)

6536 OS Comparative analysis of the numerical diffraction models [6536-27]

D. Proskurin, N. Pechenkin, A. Zemtzov, Voronezh State Univ. of Architecture and Civil

Engineering (Russia)

\section{SESSION 4 OPTICAL AND ACOUSTICAL METHODS FOR TESTING AND IMAGING}

6536 OT Improved stereoscopic imaging with converged camera configuration [6536-28]

V. V. Petrov, K. A. Grebenyuk, Saratov State Univ. (Russia)

6536 OU Novel optical MEMS device technology for optical networking [6536-29]

R. Narendra, B.N.M. Institute of Technology (India); J. N. McMullin, Univ. of Alberta (Canada)

6536 OV Low-frequency acoustical defectoscopy [6536-30]

V. Chirkov, V. Petrov, S. Lapin, A. Ivannikov, Y. Norov, Saratov State Univ. (Russia)

6536 OW Method of ball-rim contact point finding in the ball bearings [6536-31]

V. Chirkov, V. Petrov, S. Lapin, I. Kozhevnikov, SpectrAcoustics Corp., Saratov State Univ. (Russia)

6536 OX Estimation of B-carotene content in flour using color analysis of reflected light [6536-32]

L. E. Dolotov, Y. P. Sinichkin, Saratov State Univ. (Russia); S. V. Tuchin, Saratov Research

Institute of the South-East (Russia)

6536 OY Optical diagnostics of growing interfaces dynamics in porous media: model and experimental verification [6536-33]

M. S. Novikov, Saratov State Univ. (Russia); D. A. Zimnyakov, Saratov State Univ. (Russia) and Institute of Precision Mechanics and Control (Russia)

$65360 Z$ Improved Kubelka-Munk approach for determination of tissues optical properties in biomedical noninvasive reflectance spectroscopy [6536-34]

L. G. Lapaeva, D. A. Rogatkin, Moscow Regional Research and Clinical Institute MONIKI (Russia)

Author Index 


\section{Conference Committees}

Annual International Multidisciplinary School for Young Scientists and Students on Optics, Laser Physics, and Biophysics

Conference Chair

Valery V. Tuchin, Saratov State University (Russia)

General Organizing Committee Chair

Dmitry A. Zimnyakov, Saratov State University (Russia)

Members

Garif G. Akchurin, Saratov State University (Russia)

Edmund I. Akopov, SPIE Russia Chapter

Alexey N. Bashkatov, Saratov State University (Russia)

Kirill V. Berezin, Saratov State University (Russia)

Anna A. Firsova, Institute of Business and Business Administration of Saratov State Technical University (Russia)

Elina A. Genina, Saratov State University (Russia)

Andrey I. Konyukhov, Saratov State University (Russia)

Nina A. Lakodina, Saratov State University (Russia)

Vladislav V. Lychagov, Saratov State University (Russia)

Ol'ga A. Perepelitsina, Saratov State University (Russia)

Georgy V. Simonenko, Saratov State University (Russia)

Maxim A. Vilensky, Saratov State University (Russia)

Nadezhda V. Ugrumova, Saratov State University (Russia)

Maria V. Storozhenko, Saratov State University (Russia)

Internet Group Chairs

Dmitry Agafonov, Saratov State University (Russia)

Ivan V. Fedosov, Saratov State University (Russia)

Members

Georgy V. Simonenko, Saratov State University (Russia)

Mikhail M. Stolnitz, Saratov State University (Russia)

Igor V. Krutikhin, Saratov State University (Russia) 
Workshop on Coherent Optics of Ordered and Random Media VII \& Seminar on Nanostructures and Nanoparticles: Fabrication, Properties, and Applications

Workshop Chair

Dmitry A. Zimnyakov, Saratov State University (Russia)

Seminar Chair

Nikolai G. Khlebtsov, Institute of Biochemistry and Physiology of Plants and Microorganisms of RAS and Saratov State University (Russia)

Secretary

Liana V. Kuznetsova, Saratov State University (Russia)

International Program Committee

Oleg V. Angelsky, Chernivtsy State University (Ukraine)

J.D. Briers, Kingston University (United Kingdom)

Vladimir L. Derbov, Saratov State University (Russia)

Victor V. Kotlyar, IPSI, Samara (Russia)

Leonid A. Melnikov, Saratov State University (Russia)

Alina N. Ponyavina, Institute of Atomic and Molecular Physics NAS (Belarus)

Vladimir P. Ryabukho, Saratov State University (Russia)

Valery V. Tuchin, Saratov State University (Russia)

Sergey S. Ulyanov, Saratov State University (Russia)

Jun Uozumi, Hokkai-Gakuen University (Japan)

Alexander G. Ushenko, Chernivtsy State University (Ukraine)

Lecture Session Chair

Dmitry A. Zimnyakov, Saratov State University (Russia)

Oral Session Chair

Nikolai G. Khlebtsov, Institute of Biochemistry and Physiology of Plants and Microorganisms of RAS and Saratov State University (Russia)

Poster Sessions

Alexander G. Akchurin, Saratov State University (Russia)

Dmitry V. Lyakin, Saratov State University (Russia)

Internet Plenary Session

Alexander V. Priezzhev, M.V. Lomonosov Moscow State University (Russia) Valery V. Tuchin, Saratov State University (Russia)

Discussion via Internet

Alexander V. Priezzhev, M.V. Lomonosov Moscow State University (Russia) 


\section{Introduction}

This volume of the Proceedings of SPIE contains selected contributions presented at the workshop on Coherent Optics of Ordered and Random Media VII. These presentations, as a part of the International School for Young Scientists and Students on Optics, Laser Physics, and Biophysics (Saratov Fall Meeting 2006) took place in Saratov, Russia, 26-30 September 2006. The Saratov Fall Meeting 2006 (SFM 2006) also included workshops on Optical Technologies in Biophysics and Medicine VIII, Laser Physics and Photonics VIII, Spectroscopy and Molecular Modeling VII, and other workshops.

The general topics of the workshop on Coherent Optics of Ordered and Random Media VII are:

- Nanostructures and nanoparticles: optical properties and applications

- Optical polarimetry: fundamentals and applications

- Coherence-domain techniques

- Optical and acoustical methods for testing and imaging

More than 60 participants from Russia, the United States, the United Kingdom, Germany, Finland, Ukraine, and other countries attended the workshop and seminar. Many invited and submitted presentations were the result of scientific collaboration between research groups from different countries, supported by international and national scientific foundations. We hope that this volume will be a contribution to the further development of basic principles and applications of optical technologies. Also, we hope that this proceedings book will be useful for researchers, engineers, and students specializing in the field of modern optics.

We wish to thank all the authors for their contributions to this volume. Along with our colleagues, SFM 2006 organizers Profs. V. V. Tuchin, L. A. Melnikov, V. L. Derbov, V. I. Berezin, L. M. Babkov, V. P. Ryabukho, and V. I. Kochubey, we wish to thank all the sponsoring organizations, programs, and persons for their support of the SFM2006 School, including the Russian Foundation for Basic Research, SPIE Russia Chapter, Saratov State University SPIE Student Chapter, U.S. Civilian Research \& Development Foundation for the Independent States of the Former Soviet Union (CRDF), "Almus", Ltd (Russia), Erudite-96, Ltd (Russia).

Also, we would like to thank the workshop and Seminar secretary, Liana $\vee$. Kuznetsova, and members of the organizing committee for their great help in workshop organization.

Dmitry A. Zimnyakov Nikolai G. Khelbtsov 
Downloaded From: https://www.spiedigitallibrary.org/conference-proceedings-of-spie on 26 Apr 2023

Terms of Use: https://www.spiedigitallibrary.org/terms-of-use 